\title{
Sulphur alters NFкB-p300 cross-talk in favour of p53-p300 to induce apoptosis in non-small cell lung carcinoma
}

\author{
SHILPI SAHA $^{1 *}$, PUSHPAK BHATTACHARJEE $^{1 *}$, DEBLINA GUHA $^{1}$, KIRTI KAJAL $^{1}$, POULAMI KHAN ${ }^{1}$, \\ SREEPARNA CHAKRABORTY ${ }^{1}$, SHRAVANTI MUKHERJEE ${ }^{1}$, SHRUTARSHI PAUL ${ }^{1}$, RAJKUMAR MANCHANDA ${ }^{2}$, \\ ANIL KHURANA $^{2}$, DEBADATTA NAYAK ${ }^{2}$, RATHIN CHAKRABARTY ${ }^{3}$, GAURISANKAR SA $^{1}$ and TANYA DAS ${ }^{1}$ \\ ${ }^{1}$ Division of Molecular Medicine, Bose Institute, P1/12, CIT Scheme VIIM, Kolkata-700054; \\ ${ }^{2}$ Central Council for Research in Homeopathy, 61-65 Institutional Area, Janakpuri, New Delhi-110058; \\ ${ }^{3}$ Bholanath Chakrabarty Trust, 5 Subol Koley Lane, Howrah 711101, India
}

Received March 25, 2015; Accepted May 25, 2015

DOI: 10.3892/ijo.2015.3061

\begin{abstract}
Adverse side effects of chemotherapy during cancer treatment have shifted considerable focus towards therapies that are not only targeted but are also devoid of toxic side effects. We evaluated the antitumorigenic activity of sulphur, and delineated the molecular mechanisms underlying sulphurinduced apoptosis in non-small cell lung carcinoma (NSCLC) cells. A search for the underlying mechanism revealed that the choice between the two cellular processes, $\mathrm{NF \kappa Bp} 65$-mediated survival and p53-mediated apoptosis, was decided by the competition for a limited pool of transcriptional coactivator protein p300 in NSCLC cells. In contrast, sulphur inhibited otherwise upregulated survival signaling in NSCLC cells by perturbing the nuclear translocation of $\mathrm{p} 65 \mathrm{NF} \kappa \mathrm{B}$, its association with p300 histone acetylase, and subsequent transcription of Bcl-2. Under such anti-survival condition, induction of p53-p300 cross-talk enhanced the transcriptional activity of p53 and intrinsic mitochondrial death cascade. Overall, the findings of this preclinical study clearly delineated the molecular mechanism underlying the apoptogenic effect of the non-toxic homeopathic remedy, sulphur, in NSCLC cells.
\end{abstract}

\section{Introduction}

In the present scenario lung cancer is the leading cause of cancer-related deaths worldwide and the incidence of lung cancer has almost reached epidemic proportions in both developing and developed countries (1). Despite decades of research,

Correspondence to: Professor Tanya Das or Professor Gaurisankar Sa, Division of Molecular Medicine, Bose Institute, P-1/12, CIT Scheme VII M, Kolkata-700 054, India

E-mail: tanya@jcbose.ac.in

E-mail: gauri@jcbose.ac.in

*Contributed equally

Key words: apoptosis, Bax, Bcl-2, cancer, homeopathy, NFkB, p300, p53, sulphur the available treatment options for lung cancer patients remain inadequate, either to offer a cure or even a substantial survival advantage owing to its inherent resistance to chemotherapy. Moreover, the clinical efficacy and usefulness of chemotherapy is still limited because of its dose-limiting toxicity (2) which has considerably shifted the focus towards complementary and alternative medicine (CAM), that are low in toxic side effects (3). Among different CAM regimens, homeopathy a nearly 200-year-old system of medicine has been shown to decrease side effects of chemotherapy in cancer patients and possess antitumorigenic property (4-8). Homeopaths have described observations that tumors recede from the use of homeopathic treatment and have, from time to time, documented long-term recoveries from cancer in response to homeopathic treatment (4-6). Unfortunately, scientific studies corroborating these clinical observations are very few. There are only few reports on the mechanism of action of homeopathic drugs in experimental cancers and cell cultures (9-14).

In the present study, we investigated the basic molecular mechanism of antitumorigenic effect of sulphur, a promising homeopathic remedy, on non-small cell lung cancer cells. Sulphur, the most ancient archetype in the history of our planet, is used by homeopaths for treating inflammation and cancer and also in treating other skin diseases (15-18). Potent chemopreventive effects have been demonstrated in various in vivo and in vitro models for sulphur-containing compounds found in naturally occurring products, such as, onions and garlic $(19,20)$. Protective effect of sulphur has also been reported against cytotoxicity in neuroblastoma cells (21). In vitro treatment with sulphur significantly increased apoptosis in neuroblastoma cells (22). Reports have stated growth inhibitory and apoptosis-related effects of sulphur on immortalized human oral keratinocytes and on oral cancer cells (23). Taken together, these findings indicate a promising anticancer potential of sulphur. However, the underlying mode of action for its professed antitumorigenic effect in highly resistant non-small cell lung carcinoma (NSCLC) is still unidentified and requires further study. To the best of our knowledge, therefore, this is the first report delineating the detailed mechanism of sulphur on NSCLC cells. 
It is well established that development and growth of tumor cells are controlled by complex signalling pathways involved in the regulation of cell death, survival and proliferation. In mammalian cells, the regulatory contribution of NFkB and p53 to cancer development and progression is well documented where inactivation of p53 and hyperactivation of NFKB are the common occurrences (24-27). It has been acknowledged that NFKB pathway activation renders inherent resistance to chemotherapy to NSCLC cells apparently via induction of survival and anti-apoptotic proteins $(25,28)$. Therefore, targeting NFkB pathway may serve as a novel approach to regress NSCLC cells. Conversely, tumor suppressor p53, the 'guardian of genome' translates stress signals into cell cycle arrest or apoptosis, depending on the balance between pro-apoptotic and anti-proliferative genes (29-31). Thus, drugs reviving tumor suppressor functions of p53 will be proficient for targeted cancer therapy. Considering the deregulation of $\mathrm{NF \kappa B}$ and p53 pathways in numerous cancers, including NSCLC cells, it is not surprising that extensive cross-talk between these pathways exists at various levels. In fact, NFKB activation was shown to play a role in neoplastic transformation by inhibiting p53 gene expression $(32,33)$. Moreover, reports have shown that NFאB by inducing the E3 ubiquitin ligase MDM2 attenuated p53 protein stability (34). Furthermore, the NFאB gene promoter is activated by $\mathrm{p} 53$ mutants, and p52 subunit of $\mathrm{NF \kappa B}$ can modulate the promoter activity of p53 target genes (34). Both NFאB and p53 compete for co-activators, for example, the histone acetyltransferases p300 and CBP $(35,36)$. An ideal therapeutic approach should, therefore, involve tailoring NFkB-governed survival pathway in favor of p53-regulated apoptotic pathway to regress otherwise drug-resistant NSCLC cells.

The present study investigated the molecular mechanism underlying the antitumorigenic potential of homeopathic remedy sulphur, commonly known as a healing mineral. Our findings revealed that sulphur preferentially induces apoptosis in NSCLC cells sparing normal cells. Our exploration for the detailed molecular mechanism revealed that sulphur inhibits $\mathrm{NF \kappa B}$-induced Bcl-2 mediated survival pathway while triggering p53-induced Bax mediated apoptosis in NSCLC cells. In NSCLC cells, the constitutively active $\mathrm{NF \kappa B}$ associates with p300 and this NFKB-p300 complex binds to the promoter region of $\mathrm{Bcl}-2$ thereby leading to transcriptional upregulation of $\mathrm{Bcl} 2$ that in turn endorses activation of survival pathway. On the contrary, upon sulphur treatment, pro-apoptotic gene p53 gets activated and occupies p300 to form p53-p300 complex. NFкB-p300 complex formation, therefore, gets hampered and the newly formed p53-p300 complex binds to the promoter region of p53 target gene, Bax thereby leading to the transcriptional upregulation of Bax that consecutively directs activation of apoptotic pathway. Sulphur thus plays an essential role in dictating pro and anti-apoptotic permutation to create an environment conducive for induction of apoptosis in NSCLC cells.

\section{Materials and methods}

Cell culture. Human non-small cell carcinoma cell line, A549 was obtained from NCCS, India. Peripheral blood collected from healthy human volunteers with informed consent (Institutional Review Board 1382) was centrifuged over Ficoll-Hypaque density gradient (Amersham Pharmacia, Uppsala, Sweden) to obtain total peripheral blood mononuclear cells. Cells were routinely maintained in DMEM supplemented with $10 \%$ heat inactivated fetal bovine serum (Lonza, NH, USA), L-glutamine ( $2 \mathrm{mM})$, sodium pyruvate $(100 \mu \mathrm{g} / \mathrm{ml})$, non-essential amino acids $(100 \mu \mathrm{M})$, streptomycin $(100 \mu \mathrm{g} / \mathrm{ml})$, penicillin $\left(50 \mathrm{U} / \mathrm{ml}\right.$; Invitogen, CA, USA) at $37^{\circ} \mathrm{C}$ in a humidified $5 \% \mathrm{CO}_{2}$ incubator. Cells were maintained in an exponential growth phase for all experiments. Viable cell numbers were determined by trypan-blue exclusion test.

Treatment of cells. Placebo and sulphur 6C, 30C or 200C were procured from Hahnemann Publishing Co., India. Cells were treated with sulphur/placebo of potencies 6,30 or $200 \mathrm{C}$ exposure at the different concentration $(10,15,20$ and $30 \mu \mathrm{l} / \mathrm{ml})$ for different time-points $(6,12,24,36$ and $48 \mathrm{~h})$ to select the optimum time required for cell killing. To understand the sequence of events leading to apoptosis, cancer cells were treated with mitochondrial pore inhibitor CsA ( $25 \mu \mathrm{M}$; Merck, Germany) for $1 \mathrm{~h}$ prior to incubation with sulphur.

Flow cytometry. For the determination of cell death, cells were stained with 7AAD and Annexin V-FITC and analyzed on flow cytometry (FACS Verse, BD Biosciences). Electronic compensation of the instrument was done to exclude overlapping of the emission spectra. A total of 10,000 events were acquired for analysis using CellQuest software. For the assessment of mitochondrial transmembrane potential, cells were stained with potentially-sensitive dye Dihexyloxacarbonicao cyanine ( DiOC $_{6}$, Merck, Germany) during the last $30 \mathrm{~min}$ of treatment at $37^{\circ} \mathrm{C}$ in the dark. Fluorescence of retained $\mathrm{DiOC}_{6}$ was determined flow cytometrically using logarithmic amplification by CellQuest software (BD Biosciences) (31).

Fluorescence imaging. Chromatin condensation and nuclear fragmentation was analyzed using the standard protocol. Briefly, cells were grown on coverslips, fixed with $3 \%$ p-formaldehyde for $10 \mathrm{~min}$ and then permeabilized with $0.1 \%$ Triton $\mathrm{X}-100$ for 5 min. Cells were then incubated with 4'6-diamidino-2-phenylindole (DAPI; BD Pharmingen, CA, USA). The morphology of the cell nuclei was visualized using a fluorescence microscope (Leitz microscope fitted with epifluorescence illuminator through a $60 \mathrm{X}$ aperture oil immersion lens, Carl Zeiss, Germany). For fluorescence imaging, cells growing on a cover slip were fixed with $3 \%$ p-formaldehyde and were stained with anti-p53 and anti-p65NFkB antibodies (SantaCruz, CA, USA), after permeabilization with Triton X-100, followed by FITC and TRITC conjugated secondary antibodies, respectively and visualized with confocal microscope (Carl Zeiss, Germany) $(13,37)$.

Plasmids, siRNA and transfections. The expression constructs pcDNA3.0/HA-tagged I $\kappa \mathrm{B} \alpha-32 \mathrm{~A} / 36 \mathrm{~A}[\mathrm{I} \kappa \mathrm{B} \alpha$ super-repressor (I $\kappa \mathrm{B} \alpha-\mathrm{SR}$ ), a kind gift from Dr J. Didonato, The Cleveland Clinic Foundation], pcDNA3.1-p65NFkB/p53/Bcl-2 overexpression plasmids ( $2 \mu \mathrm{g} / \mathrm{million}$ cells) were introduced into exponentially growing cancer cells using Lipofectamine 2000 (Invitrogen, Carlsbad, CA, USA) according to the protocol provided by the manufacturer. In a similar manner, p53 
expression was knocked down in A549 cells using p53-shRNA (Santa Cruz) and Lipofectamine 2000 (Invitrogen). Stably expressing clones were isolated by limiting dilution and selected with G418 sulphate (Cellgro) at a concentration of $400 \mu \mathrm{g} / \mathrm{ml}$ and cells surviving this treatment were cloned and screened by western blot analysis with specific antibody. A549 cells were transfected with 300 pmol of Bcl-2-/Bax-/controlds-siRNA (Santa Cruz) and Lipofectamine 2000 separately for $12 \mathrm{~h}$. The levels of respective proteins were estimated by western blotting (37).

Western blotting. To obtain whole cell lysates, cells were homogenized in lysis buffer (20 mM HEPES, pH 7.5, $10 \mathrm{mM}$ $\mathrm{KCl}, 1.5 \mathrm{mM} \mathrm{MgCl}{ }_{2}, 1 \mathrm{mM}$ Na-EDTA, $1 \mathrm{mM}$ Na-EGTA and $1 \mathrm{mM}$ DTT) supplemented with protease and phosphatase inhibitor cocktails. Mitochondrial and cytosolic fractions were prepared according to Lahiry et al (31). For direct western blot analysis, a total of $50 \mu \mathrm{g}$ of protein was resolved using SDS-PAGE and transferred to nitrocellulose membrane for western blotting using required antibodies e.g., anti-caspase-9,

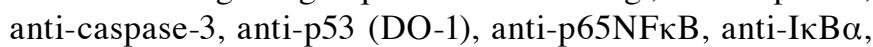
anti-Bcl-2, anti-Bax (N-20), anti-cytochrome $c$ and anti-p300. Thereafter proteins of interest were visualized by chemiluminiscence. Equivalent protein loading in cytosolic, nuclear and mitochondrial fractions were verified using anti- $\alpha$-actin/ histone H1/MnSOD antibodies (Santa Cruz, CA, USA) respectively.

Co-immunoprecipitation. For the determination of direct interaction between two proteins, co-immunoprecipitation technique was employed $(38,39)$. p53-p300 and p65NFкB-p300 interaction was determined by co-immunoprecipitation. Samples (300 $\mu \mathrm{g}$ of protein from the total lysate) were incubated at $4^{\circ} \mathrm{C}$ overnight with anti-p300/-IgG antibody and then incubated for $2 \mathrm{~h}$ at $4^{\circ} \mathrm{C}$ with protein A-Sepharose. Immunocomplexes were washed of unbound proteins with cold TBS with protease inhibitors, and pelleted beads were boiled for $5 \mathrm{~min}$ in SDS-PAGE sample buffer. The immunoprecipitated proteins were resolved on SDS-PAGE and analyzed by western blotting for detection of associated proteins. Equal protein loading was confirmed using anti-histone $\mathrm{H} 1$ antibody.

Reverse transcriptase-PCR. Total RNA (2 $\mu \mathrm{g})$ each from untreated, placebo-/sulphur-treated NSCLC cells was extracted by TRIzol (Invitrogen) and was reverse transcribed and then subjected to PCR with enzymes and reagents of the RTplusPCR System (Eppendorf, Hamburg, Germany) using GeneAmpPCR 2720 (Applied Biosystems, Foster City, CA, USA) (40). The cDNAs were amplified with primers specific for Bax (5'-GGAATTCCAAGAAGCTGAGCGAGTGT-3' 5'-GGAATTCTTCTTCCAGATGGTGAGCGAG-3'), Bcl-2 (5'-CCTGTGCCACCATGTGTCCATC-3'/5'-GCTGAGAACA GGGTCTTCAGAGAC-3') and GAPDH (internal control: 5'-TGATGACATCAAGAAGGTGGTGAAG-3'/5'-TCCTTGG AGGCCATGTAGGCCAT-3').

Chromatin immunoprecipitation (ChIP). ChIP assays were carried out for identification of p53 and p65NF $\mathrm{B}$ binding region on Bax and Bcl-2-promoters respectively, using a ChIP assay kit (Millipore) according to the manufacturer's instructions. PCR assay was performed using primer sets as follows: Bcl-2 forward primer 5'-GATTCCTGCGGATTGACA TTTC-3', Bcl-2 reverse primer 5'-CATCAATCTTCAGCACTC TCC-3'; Bax forward primer 5'-TCAGCACAGATTAGTTT CTG-3', Bax reverse primer 5'-GGGATTACAGGCATGAG CTA-3'. Extracted DNA $(2 \mu 1)$ was used for 45 cycles of amplification in $5 \mu \mathrm{l}$ of reaction mixture under the following conditions: $95^{\circ} \mathrm{C}$ for $30 \mathrm{sec}, 56^{\circ} \mathrm{C}$ for $30 \mathrm{sec}$ and $72^{\circ} \mathrm{C}$ for $60 \mathrm{sec}$. The PCR products were analysed by $2 \%$ agarose gel electrophoresis $(41,42)$.

Statistical analysis. Values are shown as standard error of mean, except when otherwise indicated. Data were analyzed and, significance $(\mathrm{P}<0.05)$ of the differences between mean values was determined by a Student's t-test.

\section{Results}

Sulphur induces non-small cell carcinoma apoptosis. The effect of sulphur, a homeopathic drug, on the viability of human NSCLC cell line (A549) and normal peripheral blood mononuclear cell (PBMC) was examined at different potencies of sulphur, i.e., 6C, 30C, 200C, where for each potency a differential dose of $0-30 \mu \mathrm{l} / \mathrm{ml}$ was applied (Fig. 1A and B). The percent cell death was scored by trypan-blue dye-exclusion assay. It was observed that among all the potencies of sulphur, $30 \mathrm{C}$ potency resulted in most significant decrease $(\mathrm{p}<0.001)$ in cell viability (Fig. 1A). Moreover, at $20 \mu \mathrm{l} / \mathrm{ml}$ dose of $30 \mathrm{C}$, the percent A549 cell death reached its optimum (Fig. 1A) while under the same conditions the PBMC viability was found to be $>90 \%$ (Fig. 1B). These results indicating the better efficacy of $20 \mu \mathrm{l} / \mathrm{ml}$ dose of 30C sulphur in A549 cell killing with minimum toxicity led us to perform all further experiments using this particular potency and dose of sulphur. The timedependent effect of sulphur 30C $(20 \mu \mathrm{l} / \mathrm{ml})$, in comparison to placebo, on A549 and PBMC cells was examined at different time intervals ( $0-48 \mathrm{~h}$ ) and percentage cell death was assessed. Sulphur 30C, at a concentration of $20 \mu \mathrm{l} / \mathrm{ml}$, exerted timedependent significant death in A549 cells (Fig. 1C). However, significant cell death in PBMCs was noted from $24 \mathrm{~h}$ onwards following the treatment (Fig. 1D).

Next, to confirm the nature of cell death as apoptosis, we utilized double labelling techniques using Annexin V-FITC/7-AAD to distinguish between apoptotic and necrotic cells. Our flow cytometric data demonstrated that in comparison to placebo-treated A549 cells, sulphur-treated unfixed A549 cells showed Annexin V-FITC binding with minimum 7-AAD binding (Fig. 1E) indicating that the mode of cell death was apoptosis but not necrosis. These findings were re-confirmed by the development of nuclear blebbing as evidenced by DAPI-stained fluorescent images of sulphurtreated A549 cells (Fig. 1F). These data together supported the notion that sulphur $30 \mathrm{C}$ asserts apoptogenic effect in the NSCLC A549 cells.

Sulphur decreases the survival advantage of NSCLC cells by perturbing nuclear translocation of $655 F \kappa B$. Since $\mathrm{p} 65 \mathrm{NF} \kappa \mathrm{B}$ has been reported to be globally involved in survival of cancer cells $(27,28,43)$, we examined whether sulphur suppresses this pathway to combat NFאB-mediated survival to induce apop- 
A

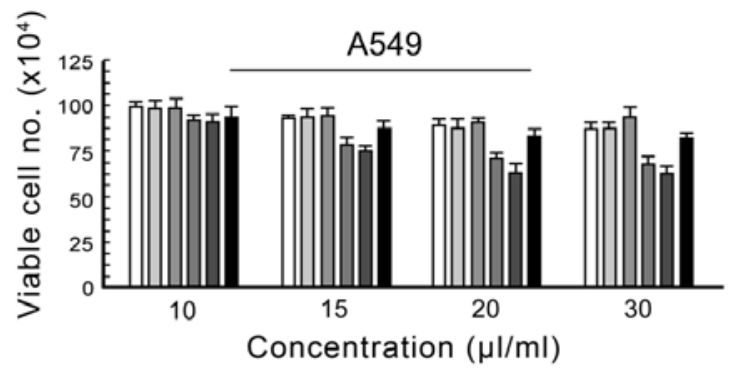

B

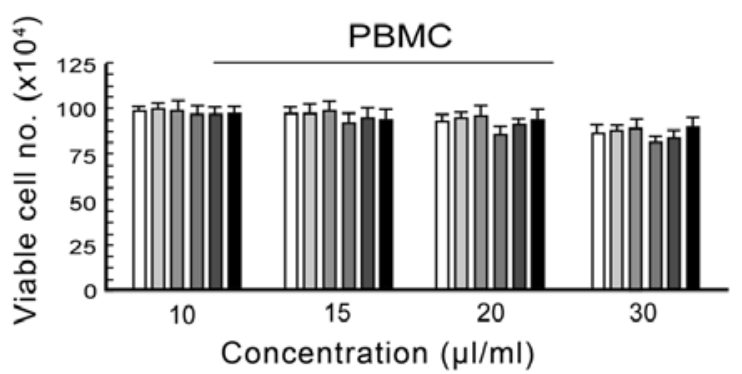

C

Placebo 6C

- Placebo $30 \mathrm{C}$

Placebo $200 \mathrm{C}$

Sulphur 6C

Sulphur 30C

Sulphur 200C

D
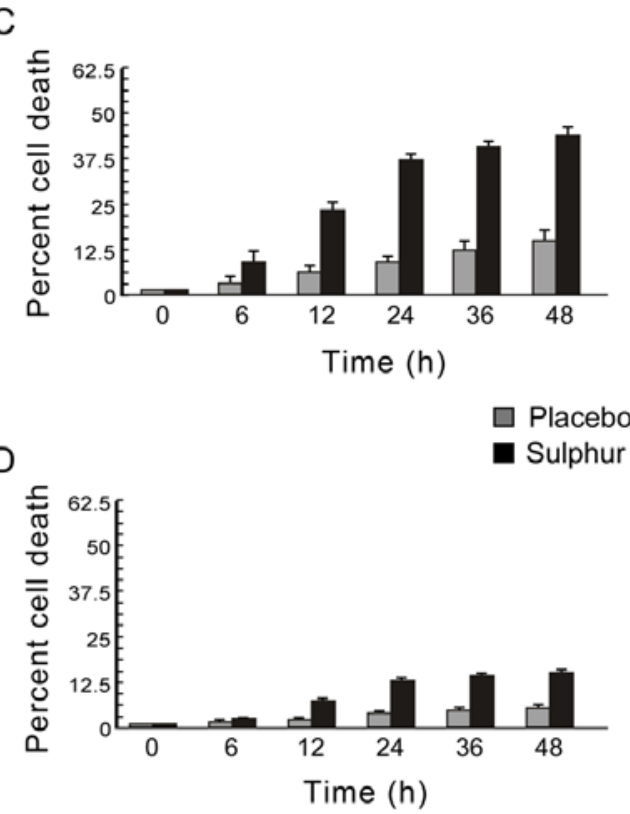

E

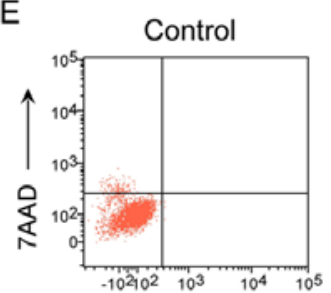

Annexin-FITC
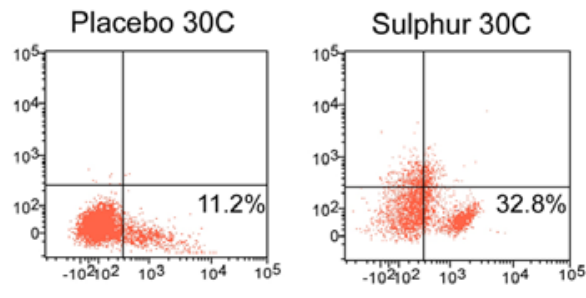
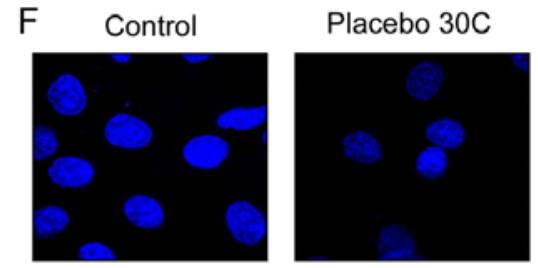

Sulphur $30 \mathrm{C}$

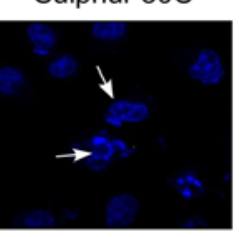

DAPI

Figure 1. Sulphur induces tumor apoptosis in NSCLC cells. (A) The number of viable A549 cells following exposure to different potencies (6C, 30C and 200C) of placebo and sulphur at different concentrations $(10,15,20$ and $30 \mu 1 / \mathrm{ml})$ was determined by trypan-blue dye exclusion assay, and the data are represented graphically $\left({ }^{*} \mathrm{P}<0.05,{ }^{* * *} \mathrm{P}<0.001\right.$ when compared with the respective placebo-treated group). (B) Graphical representation showing percentage of cell death of PBMC confirms that sulphur does not induce apoptosis in normal cells ( $\mathrm{P}<0.001$ when compared between survival percentages of un-/sulphur-treated $\mathrm{PBMCs}$ ). The percent cell death was scored by trypan-blue dye-exclusion assay. (C) Time-dependent effect of sulphur $30 \mathrm{C}$ ( $20 \mu \mathrm{l} / \mathrm{ml})$, in comparison to placebo, on A549 examined at different time intervals ( $0-48 \mathrm{~h})$. (D) Time-dependent effect of sulphur $30 \mathrm{C}(20 \mu \mathrm{l} / \mathrm{ml})$, in comparison to placebo, on PBMC was examined ( $\mathrm{P}<0.05$ and ${ }^{* *} \mathrm{P}<0.001$ when compared with respective control/treated groups). (E) The nature of sulphur induced A549 cells was assayed flow cytometrically using Annexin V-FITC/7-AAD double labelling assay. (F) DAPI staining revealed nuclear morphology of apoptotic cells (blebbing and fragmentation) as indicated by arrowheads in sulphur treated sample when visualized under a fluorescence microscope. Bar length in images indicate $20 \mu \mathrm{m}$. Values are the mean \pm SEM of three independent experiments in each case or representative of a typical experiment.

tosis in drug-resistant NSCLC cells. Our search revealed that sulphur treatment efficiently blocked nuclear translocation of NFKB in NSCLC cells as observed by both western blotting (Fig. 2A) and confocal imaging experiments (Fig. 2B). In addition, the mRNA and protein levels of NFkB-target gene, Bcl-2, was found to be downregulated by sulphur treatment in NSCLC cells (Fig. 2C). We further observed that transfecting NSCLC cells with super repressor I $\mathrm{B} \alpha$-SR-cDNA decreased Bcl-2 followed by significant apoptosis in response to sulphur (Figs. 2D and E). On the other hand NSCLC cells expressing p65NFאB-cDNA manifested enhanced Bcl-2 with significant resistance upon sulphur exposure (Fig. 2D and E). The antiapoptotic role of $\mathrm{NF} \kappa \mathrm{B}$-dependent $\mathrm{Bcl}-2$ upregulation was re-confirmed by evaluating response of Bcl-2-engineered cells towards sulphur treatment. Overexpression of Bcl-2 in NSCLC cells bestowed them with survival advantage upon sulphur treatment, whereas transfection with Bcl-2-siRNA efficiently enhanced sulphur-induced apoptosis (Fig. 2F). Collectively, these results confirmed that $\mathrm{p} 65 \mathrm{NF} \mathrm{B}$ activation and subse- quent Bcl-2 upregulation were primarily involved in survival of NSCLC cells which upon inhibition by sulphur induced apoptosis in these cells.

Sulphur treatment triggers the p53-mediated mitochondriadependent apoptotic pathway in NSCLC cells. Since inhibition of $\mathrm{p} 65 \mathrm{NF} \kappa \mathrm{B}$ activity in NSCLC cells induced a powerful apoptotic response, we predicted the involvement of the cellular apoptotic proteins during sulphur-induced apoptosis. We evaluated the status of apoptotic proteases, i.e., caspase- 9 and caspase-3, respectively, in response to sulphur treatment. It was noted that sulphur treatment significantly upregulated levels of cleaved caspase- 9 and caspase- 3 in A549 cells (Fig. 3A). Since tumor suppressor protein p53 plays an important role in canonical apoptotic pathway, the above results tempted us to compare the p53 activation status upon sulphur exposure in NSCLC cells. Results of Fig. 3B left panel revealed that sulphur induced p53 expression in A549 cells when compared to untreated cells. These results 
A

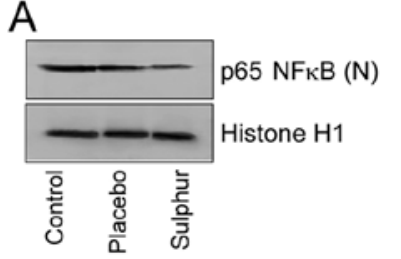

c

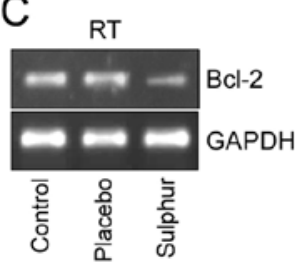

D

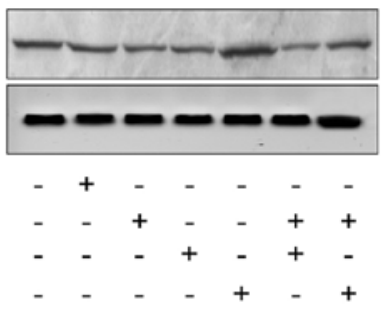

E
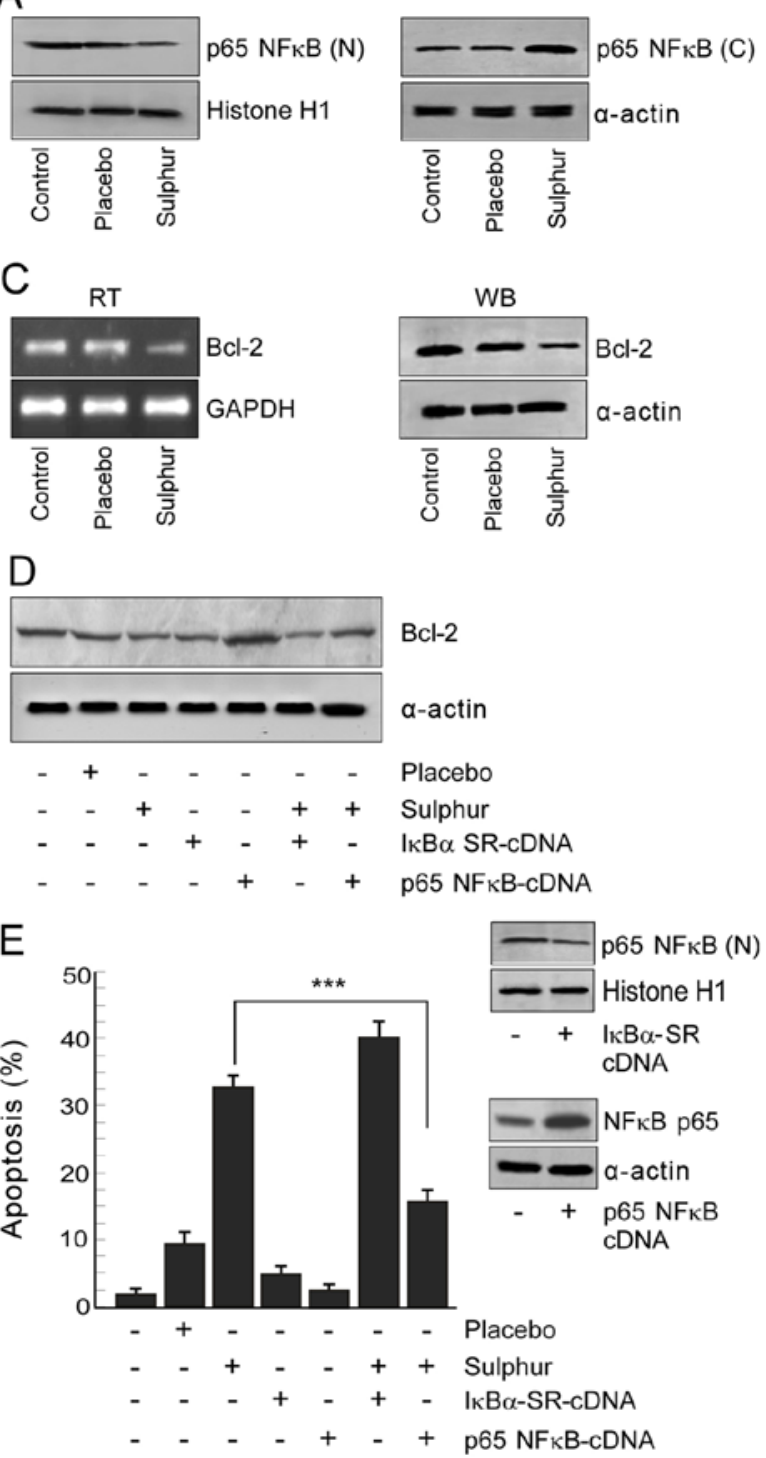

$\mathrm{Bcl}-2$

$\alpha$-actin

Placebo

Sulphur

IKB $\alpha$ SR-cDNA

p65 NFKB-CDNA
B
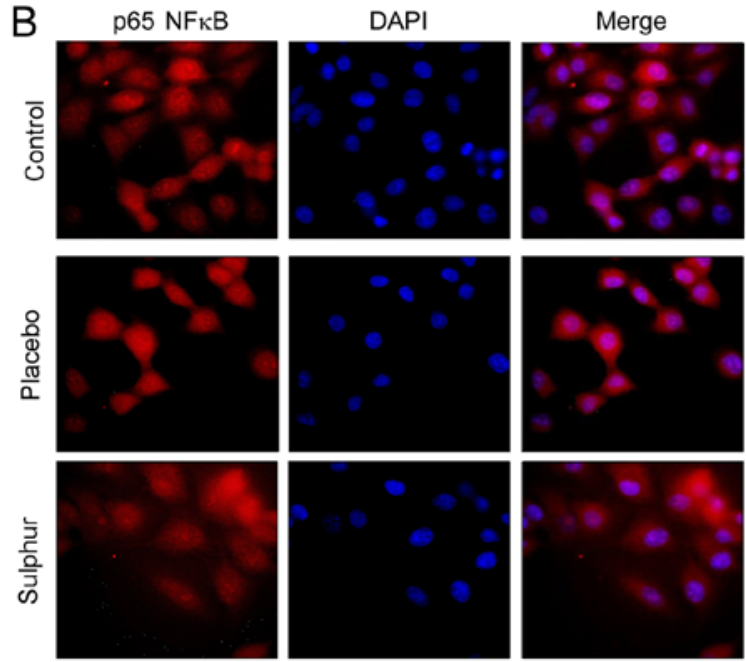

$\mathrm{F}$
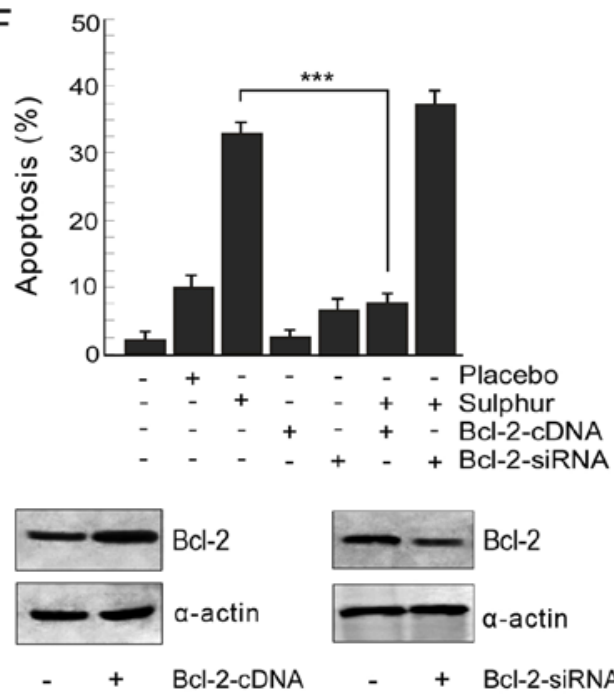

Figure 2. Sulphur decreases the survival signal of NSCLC cells by restraining nuclear translocation of NFkB. (A) Expression of nuclear (N) and cytosolic (C) p65NFkB was determined by western blot analysis in the A549 cells treated with placebo and sulphur at $30 \mathrm{C}$ (20 $\mu \mathrm{l} / \mathrm{ml})$. (B) Nuclear and cytosolic expression of p65 was visualized by confocal microscopy after fixation and permeabilization of control, placebo and sulphur treated A549 cells using the anti-p65NF $\mathrm{B}$ antibody. (C) Untreated-/placebo-/sulphur-treated A549 cells were subjected to RT-PCR/western blot analysis to determine the expression profile of Bcl-2 at

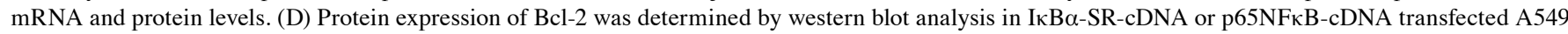
cells in the presence or absence of placebo or sulphur. (E) In a parallel experiment, the percentage of apoptosis was determined by Annexin V-FITC/7AAD staining, and data are presented graphically $\left({ }^{* * *} \mathrm{P}<0.001\right.$ when compared with the sulphur-treated group). The efficiency of I $\kappa \mathrm{B} \alpha-\mathrm{SR}-\mathrm{cDNA}$ and $\mathrm{p} 65 \mathrm{NF} \kappa \mathrm{B}-$ cDNA transfection was also verified by western blot analysis (inset). (F) Presentation of the percentage of apoptosis in Bcl-2-cDNA or Bcl-2-siRNA transfected A549 cells in the presence or absence of placebo or sulphur, as determined by Annexin V-FITC/7AAD staining (*** P $<0.001$ when compared with the sulphurtreated group). The efficiency of Bcl-2-cDNA and Bcl-2-siRNA transfection was also verified by western blot analysis (inset). $\alpha$-actin was used as an internal loading control. Values are the mean \pm SEM of three independent experiments in each case or representative of a typical experiment.

were further confirmed by confocal microscopy, the results of which not only demonstrated accumulation of p53 protein but also its translocation from cytosol to nucleus of sulphurexposed A549 cells (Fig. 3B, middle panel). Furthermore, findings of western blot analysis verified greater translocation of p53 from cytosol to nucleus upon sulphur exposure in A549 cells (Fig. 3B right panel). It is acknowledged that p53 when localized in nucleus transactivates its downstream target genes (31). We, therefore, next assessed the status of its trans-activated gene product, i.e., Bax, by western blot and RT-PCR analyses in sulphur-treated and untreated A549 cells.
Our results re-established that in comparison to un-/placebotreated tumor cells, sulphur-exposed cells showed increase in the levels of p53 trans-activated gene product Bax (Fig. 3C) Downstream of Bax, increase in cytosolic cytochrome $c$ with its concomitant decrease in mitochondria (Fig. 3D) were observed and also significant mitochondrial transmembrane potential (MTP) loss is observed in sulphur-exposed A549 cells as compared to control and placebo-treated A549 cells (Fig. 3E).

Next, A549 cells were transfected with Bax-siRNA or pre-treated with cyclosporine A (CsA), mitochondrial pore 

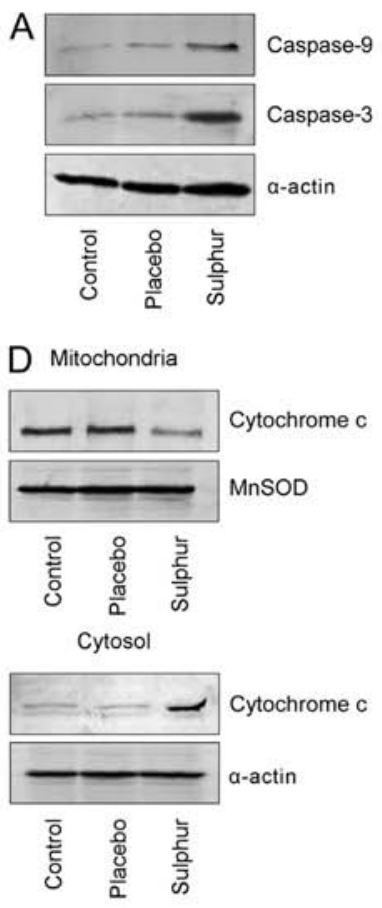
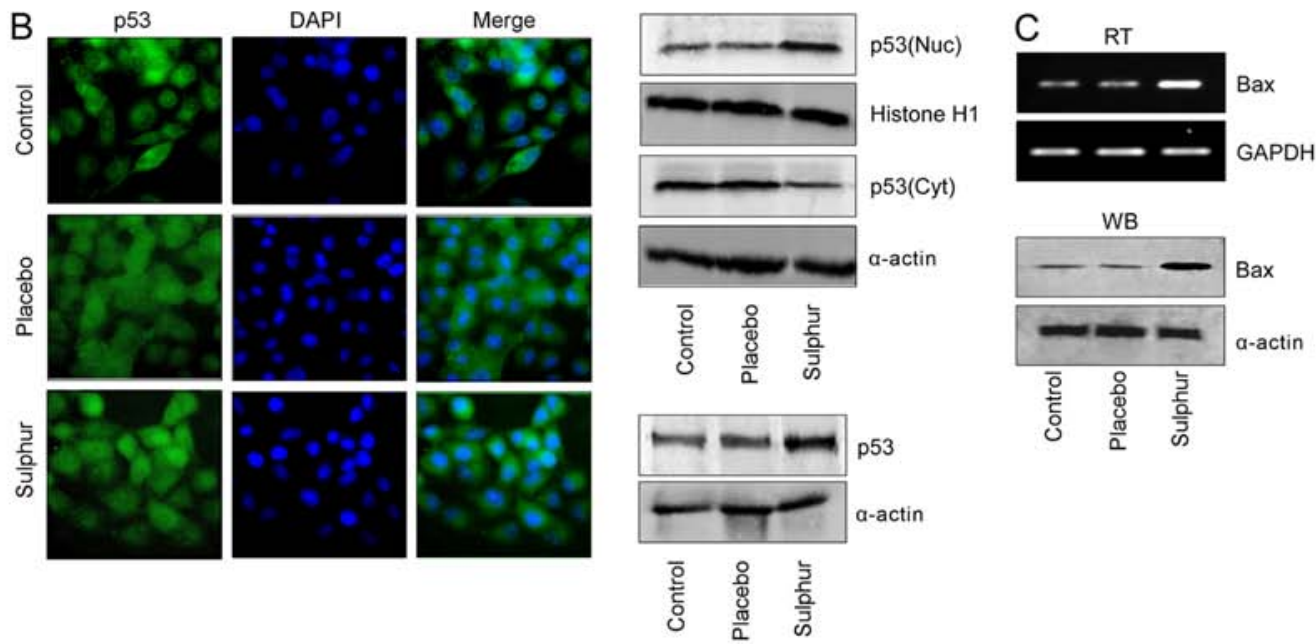
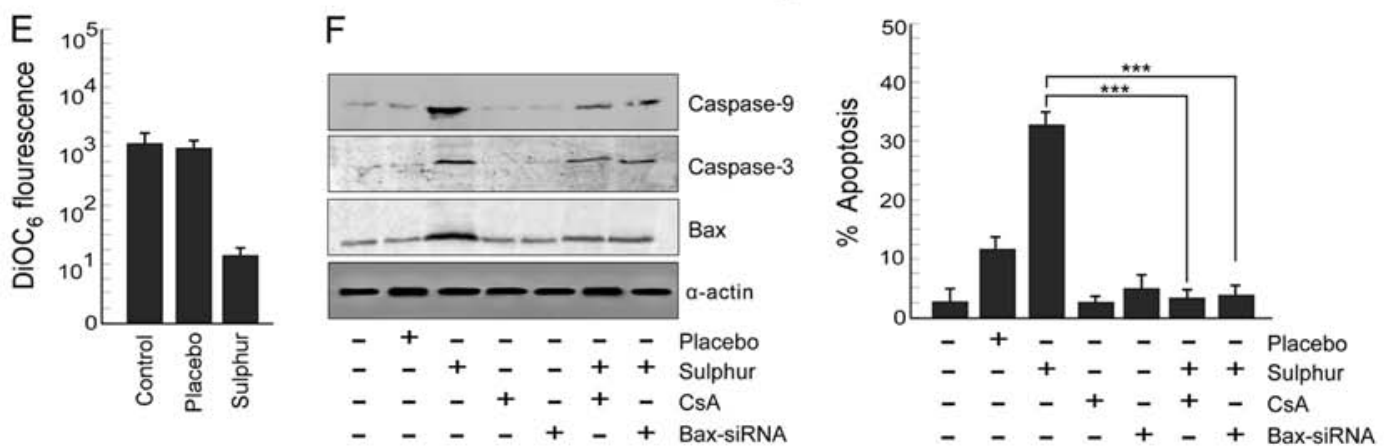

Figure 3. Sulphur treatment elicits the p53-mediated mitochondrial apoptotic pathway in A549 cells. (A) Expression profile of active caspase-3 and active caspase-9 in un-/placebo-/sulphur-treated A549 cells was observed by western blot analysis. (B) Expression of total p53 in un-/placebo-/sulphur-treated A549 cells was determined by western blot analysis (left pannel) and confocal microscopy (middle panel). Cytosolic (C) and nuclear (N) expression of p53 was observed by western blotting in un-/placebo-/sulphur-treated A549 cells (right pannel). (C) Untreated-/placebo-/sulphur-treated A549 cells were subjected to RT-PCR/western blot analysis to determine the expression profile of Bax at mRNA and protein levels. (D) Mitochondrial and cytosolic expression of Bax and cytochrome $c$ was determined by western blotting. (E) Presentation of mean $\mathrm{DiOC}_{6}$ fluorescence to determine mitochondrial transmembrane potential of untreated-/placebo-/sulphur-treated A549 cells as determined by flow cytometry. (F) Expression of Bax, active caspase- 9 and caspase-3 was observed by western blotting in control A549 cells and A549 cells transfected with Bax-siRNA or pre-treated with cyclosporine A (CsA), prior to sulphur treatment. In a parallel experiment, the percentage of apoptosis was determined by Annexin V-FITC/7AAD staining, and data are presented graphically ${ }^{* * * *} \mathrm{P}<0.001$ when compared with the sulphur-treated group). $\alpha$-actin and MnSOD was used as an internal loading control. Values are the mean \pm SEM of three independent experiments in each case or representative of typical experiment.

formation blocker, prior to sulphur treatment for validation of the involvement of Bax in mitochondria cascade-mediated NSCLC apoptosis. Silencing Bax, or CsA pre-treatment significantly decreased percent apoptosis of NSCLC cells and also down-modulated the expression levels of caspase- 9 and caspase-3 (Fig. 3F). Taken together these findings validated the contribution of Bax in sulphur-induced A549 cell apoptosis via mitochondrial death cascade.

Inhibition of $p 65 N F \kappa B$ by sulphur triggers p53-mediated apoptosis in NSCLC cells. Next, we verified whether sulphurinduced cancer cell death is p53-dependent or not. To this end, human cancer cell lines with differential p53 status, e.g., wild-type p53-expressing and p53-shRNA-transfected A549 cells were tested for sulphur-dependent apoptosis by scoring the number of Annexin V-positive cells flow cytometrically (Fig. 4A). Interestingly, sulphur $30 \mathrm{C}$ at $20 \mu \mathrm{l} / \mathrm{ml}$ dose significantly $(\mathrm{p}<0.001)$ induced apoptosis in wild-type p53-expressing A549 cells. The apoptogenic insult asserted by sulphur after minimization of placebo effect in A549 cells were 31\%, while p53-knockdown cells resisted such insult (Fig. 4A).
These results indicated the contribution of functional p53 in sulphur-induced cancer cell apoptosis.

In parallel experiment when A549 cells were transfected with p53-cDNA, p53 expression though increased, Bax expression level failed to reach that of sulphur-treated A549 cells (Fig. 4B). These findings revealed that increasing p53 levels alone in NSCLC cells failed to restore p53 transcriptional functions and to induce apoptosis (Fig. 4C). This raised the possibility of the involvement of p53 transcriptional 'inhibitor(s)' in NSCLC cells that somehow opposed p53-dependent transcription of apoptotic genes. Sulphur, on the other hand, by restraining this inhibitor might have activated the p53-transcriptional program. Since our previous results (Fig. 2A and B) have demonstrated sulphur-induced inhibition of $\mathrm{NF \kappa B}$ activation, we hypothesized that activated $\mathrm{NF \kappa B}$ might be blocking p53-dependent apoptotic program in NSCLC cells. To confirm this hypothesis we utilized I $\mathrm{B} \alpha$-SR-cDNA transfected cells and checked p53-dependent execution of apoptosis in these cells upon transfection with p53-cDNA. Indeed these transfectants displayed robust p53 induction along with upregulation of Bax (Fig. 4B). Activation 


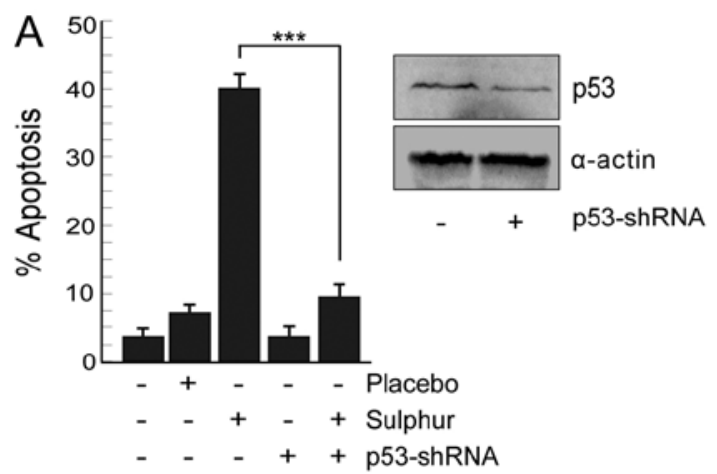

B
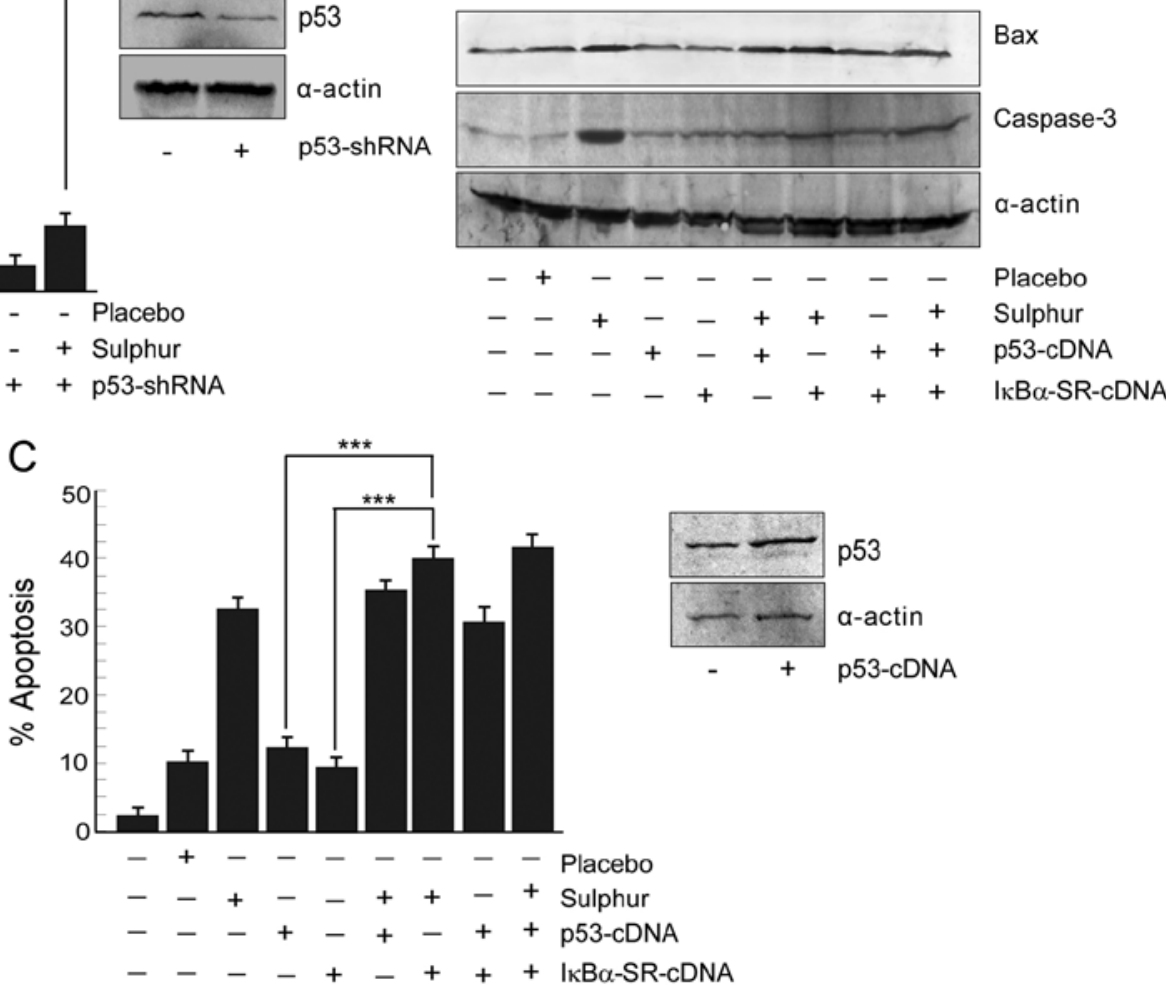

Figure 4. Sulphur ensures p53-mediated apoptosis in NSCLC cells by inhibiting p65NFkB. (A) The percentage of apoptosis was determined in control or p53shRNA transfected A549 cells in presence or absence of placebo or sulphur by Annexin V-FITC/7AAD staining, and data are presented graphically $\left({ }^{* * * *} \mathrm{P}<0.001\right.$ when compared with the sulphur-treated group). The efficiency of p53-shRNA transfection was also verified by western blot analysis (inset). (B) Protein

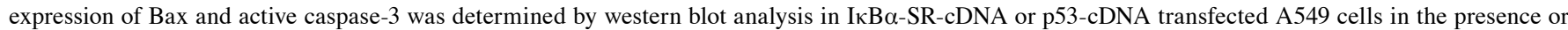
absence of placebo or sulphur at 30C $(20 \mu 1 / \mathrm{ml})$. (C) In a parallel experiment, the percentage of apoptosis was determined by Annexin V-FITC/7AAD staining, and data are presented graphically $\left({ }^{* * * *} \mathrm{P}<0.001\right.$ when compared with the sulphur-treated group). The efficiency of p53-cDNA transfection was also verified by western blot analysis (inset). $\alpha$-actin was used as an internal loading control. Values are the mean \pm SEM of three independent experiments in each case or representative of a typical experiment.

of caspase-3 in these cells (Fig. 4B) finally confirmed that $\mathrm{NF \kappa B}$ intervened the functioning of p53-dependent apoptotic program.

All these results together signified that sulphur by inhibiting p65NFкB-governed survival signalling skewed the cellular microenvironment in favor of p53-transcriptional activation to result in apoptosis.

Sulphur rescues $p 300$ from $p 65 N F \kappa B$ to establish p53-p300 collaboration in NSCLC cells. We next attempted to unveil the detail mechanisms underlying NFKB-mediated inhibition of p53 transcription functions. Recent studies indicate that the transcriptional activity of p53 is regulated by its interaction with the transcriptional co-activator p300 $(27,31)$. To verify the effects of sulphur on p53-p300 cross-talk, if any, we immunoprecipitated nuclear $\mathrm{p} 300$ in NSCLC cells treated with placebo, or sulphur and verified its interaction with $\mathrm{p} 53$ by western blotting. It was observed that in contrast to placebo, sulphur induced p53-p300 interaction (Fig. 5A). Consistently, it was further observed by ChIP analysis that sulphur treatment in NSCLC cells enhanced p53 binding on Bax promoter, which is a pre-requisite for transcriptional activation of $\mathrm{Bax}$ (Fig. 5B). This subsequently enabled p53-dependent apoptosis as observed earlier (Fig. 3A). Since, sulphur triggered p53-p300 interaction in cells where p65NF $\mathrm{B}$ activation was not taking place, we proposed that nuclear translocation of p65NFkB in untreated p53-cDNA transfected A549 cells might have sequestered p300 thereby abridging p53-p300 cross-talk. As anticipated, these untreated p53-cDNA transfected A549 cells manifested significant p65NFkB-bound p300 in their nuclear lysates (Fig. 5C). Furthermore, upon genetically perturbing nuclear translocation of $\mathrm{p} 65 \mathrm{NF} \mathrm{KB}$ in these p53-cDNA trasfected A549 cells, significant increase in p53-p300 interaction was observed with concomitant decrease in p65NFкB-bound p300 (Fig. 5D). Interestingly sulphur treatment inhibited p65NFkB-p300 cross-talk (Fig. 5E) thereby preventing $\mathrm{p} 65 \mathrm{NF} \mathrm{B}$ binding on $\mathrm{Bcl}-2$ promoter to initiate p65NFKB-mediated Bcl-2 transcription (Fig. 5F). These results indicate a competition between $\mathrm{NF} \kappa \mathrm{B}$ and $\mathrm{p} 53$ for availing p300, and depending on the relative availability, the winner, and the fate of the cells are decided.

In summary, the above results conclude that in drugresistant NSCLC cells, p65NFKB competes with p53 for the transcriptional co-activator p300 thereby inhibiting the apoptotic program and upregulates the survival-machinery of the cell. On the other hand, by inhibiting p65NFkB, sulphur censored the survival pathway thereby making p300 available for $\mathrm{p} 53$ interaction to ensure the transcription of pro-apoptotic protein Bax for effective induction of apoptosis in otherwise resistant NSCLC cells (Fig. 6). 

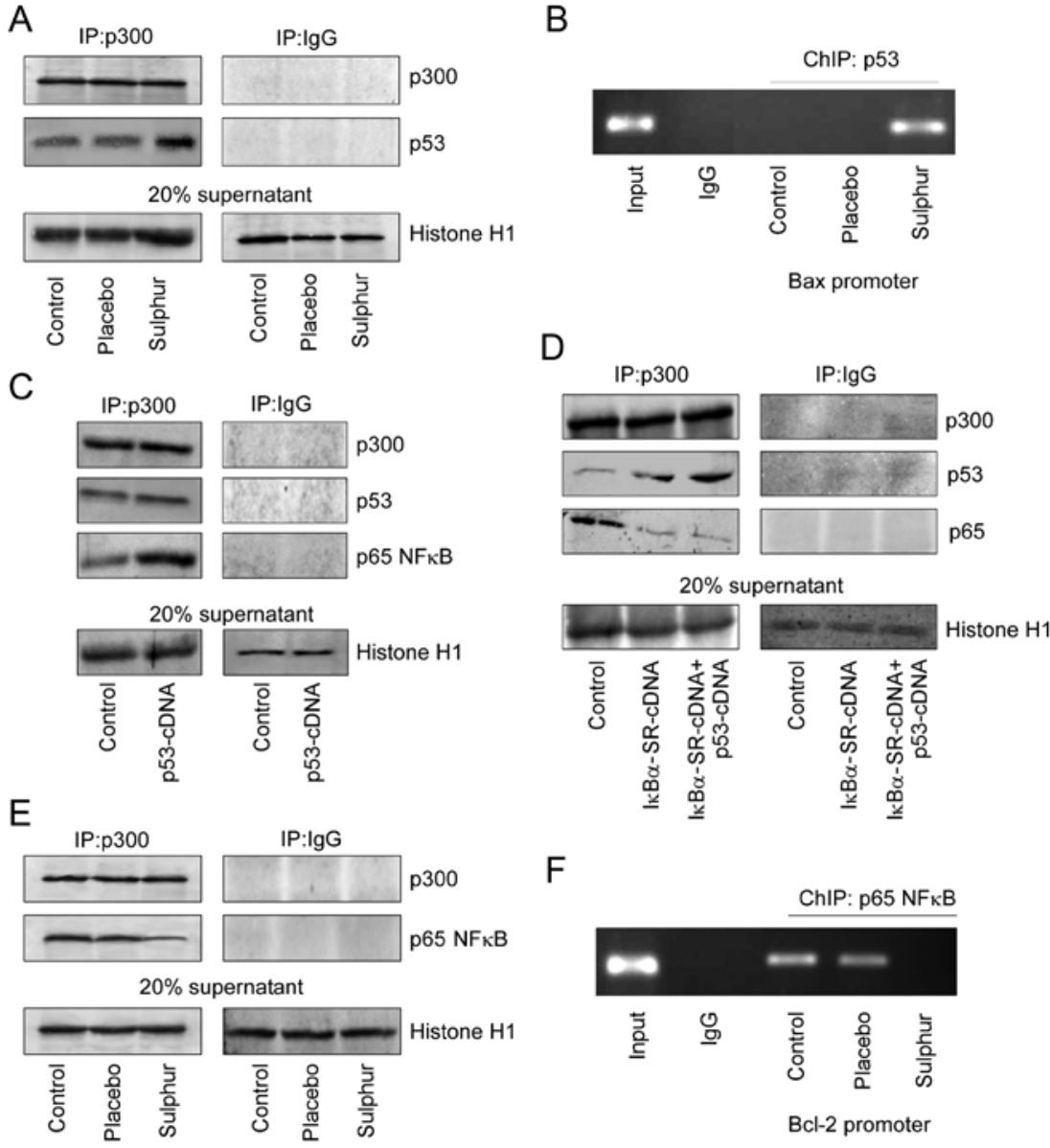

Figure 5. p53-p300 collaboration is established by sulphur, which rescues p300 from p65NFkB in NSCLC cells. (A) p53-associated p300 was immunopurified with anti-p53 antibody from nuclear lysates of un-/placebo-/sulphur-treated A549 cells and were western-blotted (WB) with p300 and p53 antibodies. (B) A portion of cells from the same experimental set were subjected to ChIP assay for the determination of p53 binding on Bax promoter. (C) p53-/p65NFkBassociated p300 was immunopurified with anti-p53/p65NFkB antibodies from nuclear lysates of control and p53-cDNA transfected A549 cells and were western-blotted (WB) with p300 antibody. (D) p53-/p65NFkB-associated p300 was immunopurified with anti-p53 and p65NFkB antibodies from nuclear

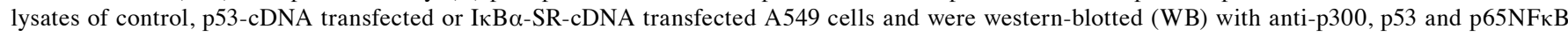
antibodies (E) p65NFkB-associated p300 was immunopurified with p65NFkB antibody from nuclear lysates of un-/placebo-/sulphur-treated A549 cells and were western-blotted (WB) with $\mathrm{p} 300$ and $\mathrm{p} 65 \mathrm{NF \kappa B}$ antibodies. (F) A portion of cells from the same experimental set were subjected to ChIP assay for the determination of $\mathrm{p} 65 \mathrm{NF} \mathrm{B}$ binding on Bcl-2 promoter. To verify comparable protein input during immunoprecipitation, $20 \%$ of supernatant from the nuclear lysates was blotted with histone H1 antibody.

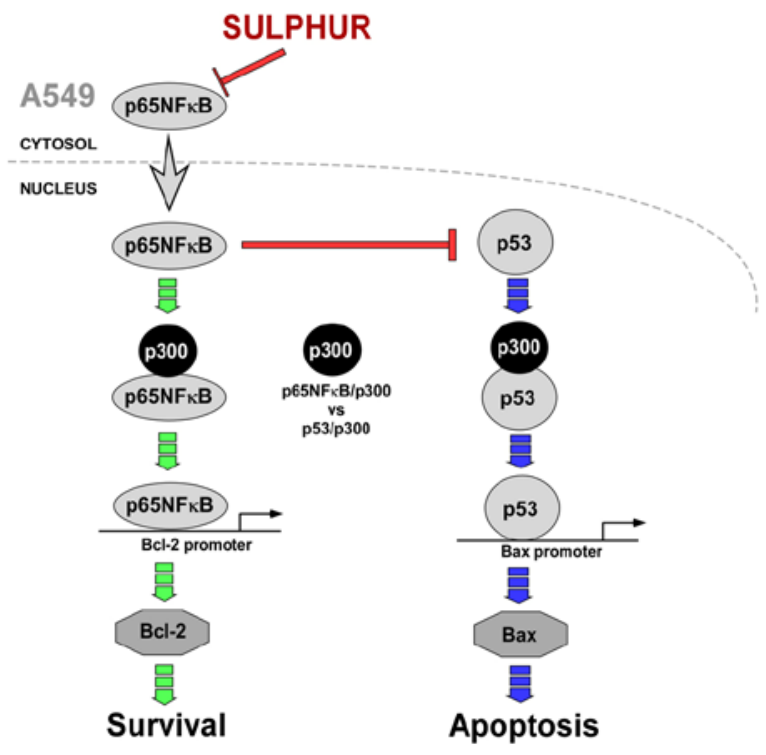

Figure 6. Schematic illustration depicting differential regulation of anti- and pro-apoptotic networks by sulphur in non-small cell carcinoma cells.

\section{Discussion}

Sulphur has been widely accredited for its antitumor potential (15-18). Although few reports have also verified the anticancer effect of this remedy $(17,19)$, detailed report elucidating the molecular mechanisms underlying the anticancer effect of sulphur is still warranted. The present study demonstrated that the antitumor effect of sulphur on non-small cell lung carcinoma cells was not a 'placebo effect' as placebo-(potentized hydro-alcoholic solution) treated cells failed to show significant death when compared to control cells. This study further revealed that sulphur asserted its effects by re-orienting the molecular choreography of cancer cells. Importantly, preferential induction of cytotoxic effects in drug-resistant NSCLC cells, as compared to normal cells, raised the exciting possibility for a window of safe and non-toxic therapeutic opportunity.

Here we report that sulphur induces apoptosis in NSCLC cells by inhibiting p65NFKB-mediated survival pathway and activating p53-apoptotic signaling. In fact, inactivation of 
$\mathrm{NF} \kappa \mathrm{B}$ pathway by sulphur rescued $\mathrm{p} 300$ from $\mathrm{p} 65 \mathrm{NF} \kappa \mathrm{B}$ and launched p53-p300 collaboration to induce p53-dependent Bax-transactivation and instigation of downstream mitochondria-dependent death cascade in NSCLC cells. The regulatory contribution of $\mathrm{NF} \mathrm{B}$ and $\mathrm{p} 53$ to cancer development and progression is well documented where inactivation of $\mathrm{p} 53$ and hyper-activation of $\mathrm{NF \kappa B}$ are the common occurrences (25-27,44). In agreement with such complex regulation of $\mathrm{NF} \kappa \mathrm{B}$ and $\mathrm{p} 53$ at several steps, these transcription factors can functionally antagonize, cooperate or exhibit independence (45-48). Likewise in our study we observed that p65NF $\kappa$ B, being activated in NSCLC cells, interfered with p53 functions by $\mathrm{p} 300$ sequestration. Inhibition of $\mathrm{p} 65 \mathrm{NF} \mathrm{KB}$ by sulphur or $\mathrm{I} \kappa \mathrm{B} \alpha$ super repressor rescued $\mathrm{p} 300$ from $\mathrm{p} 65 \mathrm{NF} \kappa \mathrm{B}$-clutch to restrain the resistance pathway. Consistently there are studies reporting that $\mathrm{p} 65 \mathrm{NF} \mathrm{KB}$ has a high-affinity for $\mathrm{p} 300$ that may lead to its sequestration thereby making it unavailable to other transcription factors (35). In line with these studies we observed that upon sulphur treatment, inhibition of $\mathrm{p} 65 \mathrm{NF} \kappa \mathrm{B}$ rescued p300 making it available to other transcription factor/s like p53 in the present case, thereby allowing p53-dependent transactivation of apoptotic proteins.

Our findings were consistent with those of Webster and Perkins (48) who first reported that the RelA (p65) subunit of $\mathrm{NF} \kappa \mathrm{B}$ antagonized p53 transactivation through sequestration of the p300 and CBP co-activators. It is acknowledged that p300 and CBP participate at various stages of the p53 response, functioning as essential co-activators in p53-dependent transactivation of target genes (49). They promote transcription of specific p53 targets by two mechanisms. First, p300 and $\mathrm{CBP}$ are recruited by 53 to target gene promoters where they acetylate histones. Secondly, p53 acetylation, secondary to DNA damage, stabilizes the p53-DNA complex at target gene promoters (49). Similarly acetylation of p $65 \mathrm{NF} \kappa \mathrm{B}$ is important for p65NF $\mathrm{B}$-DNA binding activity and p300 activation is known to enhance p65NFkB acetylation (50). The $\mathrm{N}$ - and C-terminal domains of both $\mathrm{CBP} / \mathrm{p} 300$ functionally interact with a region of $\mathrm{p} 65 \mathrm{NF} \kappa \mathrm{B}$ containing the transcriptional activation domain and thereby promote the trans-activating functions of p65NFkB transcription factors (50). Therefore, our results along with others, suggest that $\mathrm{p} 65 \mathrm{NF} \mathrm{B}$ and $\mathrm{p} 53$ compete for transcriptional co-activator $\mathrm{p} 300$ and depending upon whether p65NFkB or p53 hires p300, execution of downstream effector pathways oscillates between survival and apoptotic responses (Fig. 6).

In conclusion, our study for the first time indicated an apoptosis-inducing capability of sulphur in otherwise drugresistant NSCLC cells by shifting the cellular milieu from $\mathrm{NF} \kappa \mathrm{B}$-mediated survival environment towards p53-mediated apoptosis. Even though further investigations and clinical trials are needed, overall these findings provide evidence for a molecular signature of the apoptotic effects of sulphur on NSCLC cells.

\section{Acknowledgements}

The authors are thankful to Mr. Uttam Ghosh and Mr. Ranjan Dutta for their technical help. This study was supported by the grants from Central Council for Research in Homeopathy (CCRH), Government of India.

\section{References}

1. Dela Cruz CS, Tanoue LT and Matthay RA: Lung cancer: Epidemiology, etiology, and prevention. Clin Chest Med 32: 605-644, 2011.

2. Peters BG: An overview of chemotherapy toxicities. Top Hosp Pharm Manage 14: 59-88, 1994.

3. Cassileth BR and Vickers AJ: Complementary and alternative therapies. Urol Clin North Am 30: 369-376, 2003.

4. Barnes PM, Bloom B and Nahin RL: Complementary and alternative medicine use among adults and children: United States, 2007. Natl Health Stat Rep 12: 1-23, 2008.

5. Johannessen H, von Bornemann Hjelmborg J, Pasquarelli E, Fiorentini G, Di Costanzos F and Miccinesi G: Prevalence in the use of complementary medicine among cancer patients in Tuscany, Italy. Tumori 94: 406-410, 2008.

6. Rossi E, Vita A, Baccetti S, Di Stefano M, Voller F and Zanobini A: Complementary and alternative medicine for cancer patients: Results of the EPAAC survey on integrative oncology centres in Europe. Support Care Cancer 23: 1795-1806, 2015.

7. Flinn JE: Bromium in acute lymphatic leukemia. J Am Inst Homeopath 58: 213-214, 1965.

8. Gruchmann W: Arsenic: Destroyer and healer; a contribution to the management of carcinoma. Hippokrates 27: 444-445, 1956 (In German).

9. Saha S, Hossain DM, Mukherjee S, Mohanty S, Mazumdar M, Mukherjee S, Ghosh UK, Nayek C, Raveendar C, Khurana A, et al: Calcarea carbonica induces apoptosis in cancer cells in p53-dependent manner via an immuno-modulatory circuit. BMC Complement Altern Med 13: 230, 2013.

10. MacLaughlin BW, Gutsmuths B, Pretner E, Jonas WB, Ives J, Kulawardane DV and Amri H: Effects of homeopathic preparations on human prostate cancer growth in cellular and animal models. Integr Cancer Ther 5: 362-372, 2006.

11. Pathak S, Kumar Das J, Jyoti Biswas S and Khuda-Bukhsh AR: Protective potentials of a potentized homeopathic drug, Lycopodium-30, in ameliorating azo dye induced hepatocarcinogenesis in mice. Mol Cell Biochem 285: 121-131, 2006.

12. Frenkel M, Mishra BM, Sen S, Yang P, Pawlus A, Vence L, Leblanc A, Cohen L, Banerji P and Banerji P: Cytotoxic effects of ultra-diluted remedies on breast cancer cells. Int J Oncol 36: 395-403, 2010

13. SahaS,BhattacharjeeP,MukherjeeS,MazumdarM,Chakraborty S, Khurana A, Nayak D, Manchanda R, Chakrabarty R, Das T, et al: Contribution of the ROS-p53 feedback loop in thuja-induced apoptosis of mammary epithelial carcinoma cells. Oncol Rep 31: 1589-1598, 2014.

14. Sikdar S, Kumar Saha S and Rahman Khuda-Bukhsh A: Relative apoptosis-inducing potential of homeopathic condurango $6 \mathrm{C}$ and $30 \mathrm{C}$ in $\mathrm{H} 460$ lung cancer cells in vitro: Apoptosis-induction by homeopathic Condurango in H460 cells. J Pharmacopuncture 17: 59-69, 2014.

15. Parcell S: Sulfur in human nutrition and applications in medicine. Altern Med Rev 7: 22-44, 2002.

16. Sobolewska D, Podolak I and Makowska-Wąs J: Allium ursinum: Botanical, phytochemical and pharmacological overview. Phytochem Rev 14: 81-97, 2015.

17. Melino S, Sabelli R and Paci M: Allyl sulfur compounds and cellular detoxification system: Effects and perspectives in cancer therapy. Amino Acids 41: 103-112, 2011.

18. William boericke, homeopathic material medical http://www. homeoint.org/books/boericmm/s/sulph.html.

19. Milner JA: Mechanisms by which garlic and allyl sulfur compounds suppress carcinogen bioactivation. Garlic and carcinogenesis. Adv Exp Med Biol 492: 69-81, 2001.

20. Mikaili P, Maadirad S, Moloudizargari M, Aghajanshakeri S and Sarahroodi S: Therapeutic uses and pharmacological properties of garlic, shallot, and their biologically active compounds. Iran J Basic Med Sci 16: 1031-1048, 2013.

21. Koike S, Ogasawara Y, Shibuya N, Kimura H and Ishii K: Polysulfide exerts a protective effect against cytotoxicity caused by t-buthylhydroperoxide through Nrf2 signaling in neuroblastoma cells. FEBS Lett 587: 3548-3555, 2013.

22. Matias AC, Manieri TM, Cipriano SS, Carioni VM, Nomura CS, Machado CM and Cerchiaro G: Diethyldithiocarbamate induces apoptosis in neuroblastoma cells by raising the intracellular copper level, triggering cytochrome $c$ release and caspase activation. Toxicol In Vitro 27: 349-357, 2013. 
23. Lee J, Lee HJ, Park JD, Lee SK, Lee SI, Lim HD, Lee YM, Yun YG, Jeon BH, Ree IS, et al: Anti-cancer activity of highly purified sulfur in immortalized and malignant human oral keratinocytes. Toxicol In Vitro 22: 87-95, 2008.

24. Elmore S: Apoptosis: A review of programmed cell death Toxicol Pathol 35: 495-516, 2007.

25. Baud V and Karin M: Is NF-kappaB a good target for cancer therapy? Hopes and pitfalls. Nat Rev Drug Discov 8: 33-40, 2009.

26. Ryan KM: p53 and autophagy in cancer: Guardian of the genome meets guardian of the proteome. Eur J Cancer 47: 44-50, 2011.

27. Sen GS, Mohanty S, Hossain DMS, Bhattacharyya S, Banerjee $S$, Chakraborty J, Saha S, Ray P, Bhattacharjee P, Mandal D, et al: Curcumin enhances the efficacy of chemotherapy by tailoring p65NFKB-p300 cross-talk in favor of p53-p300 in breast cancer. J Biol Chem 286: 42232-42247, 2011.

28. Mohanty S, Saha S, Md S Hossain D, Adhikary A, Mukherjee S, Manna A, Chakraborty S, Mazumdar M, Ray P, Das K, et al: ROS-PIAS $\gamma$ cross talk channelizes ATM signaling from resistance to apoptosis during chemosensitization of resistant tumors. Cell Death Dis 5: e1021,2014.

29. Brown CJ, Lain S, Verma CS, Fersht AR and Lane DP: Awakening guardian angels: Drugging the p53 pathway. Nat Rev Cancer 9: 862-873, 2009.

30. Saha B, Adhikary A, Ray P, Saha S, Chakraborty S, Mohanty S, Das K, Mukherjee S, Mazumdar M, Lahiri L, et al: Restoration of tumor suppressor p53 by differentially regulating pro- and anti-p53 networks in HPV-18-infected cervical cancer cells. Oncogene 31: 173-186, 2012.

31. Lahiry L, Saha B, Chakraborty J, Bhattacharyya S, Chattopadhyay S, Banerjee S, Choudhuri T, Mandal D, Bhattacharyya A, Sa G, et al: Contribution of p53-mediated Bax transactivation in theaflavin-induced mammary epithelial carcinoma cell apoptosis. Apoptosis 13: 771-781, 2008.

32. Kim DS, Park SS, Nam BH, Kim IH and Kim SY: Reversal of drug resistance in breast cancer cells by transglutaminase 2 inhibition and nuclear factor-kappaB inactivation. Cancer Res 66: 10936-10943, 2006.

33. Bassères DS and Baldwin AS: Nuclear factor-kappaB and inhibitor of kappaB kinase pathways in oncogenic initiation and progression. Oncogene 25: 6817-6830, 2006

34. Lin Y, Bai L, Chen W and Xu S: The NF-kappaB activation pathways, emerging molecular targets for cancer prevention and therapy. Expert Opin Ther Targets 14: 45-55, 2010

35. Schneider G, Henrich A, Greiner G, Wolf V, Lovas A, Wieczorek M, Wagner T, Reichardt S, von Werder A, Schmid RM, et al: Cross talk between stimulated NF-kappaB and the tumor suppressor p53. Oncogene 29: 2795-2806, 2010.

36. Adhikary A, Chakraborty S, Mazumdar M, Ghosh S, Mukherjee S, Manna A, Mohanty S, Nakka KK, Joshi S, De A, et al: Inhibition of epithelial to mesenchymal transition by E-cadherin up-regulation via repression of slug transcription and inhibition of E-cadherin degradation: Dual role of scaffold/ matrix attachment region-binding protein 1 (SMAR1) in breast cancer cells. J Biol Chem 289: 25431-25444, 2014
37. Chakraborty S, Das K, Saha S, Mazumdar M, Manna A, Chakraborty S, Mukherjee S, Khan P, Adhikary A, Mohanty S, et al: Nuclear matrix protein SMAR1 represses c-Fos-mediated HPV18 E6 transcription through alteration of chromatin histone deacetylation. J Biol Chem 289: 29074-29085, 2014.

38. Chakraborty J, Banerjee S, Ray P, Hossain DM, Bhattacharyya S, Adhikary A, Chattopadhyay S, Das T and Sa G: Gain of cellular adaptation due to prolonged p53 impairment leads to functional switchover from p53 to p73 during DNA damage in acute myeloid leukemia cells. J Biol Chem 285: 33104-33112, 2010

39. Mazumdar M, Adhikary A, Chakraborty S, Mukherjee S, Manna A, Saha S, Mohanty S, Dutta A, Bhattacharjee P, Ray P, et al: Targeting RET to induce medullary thyroid cancer cell apoptosis: An antagonistic interplay between PI3K/Akt and p38MAPK/caspase-8 pathways. Apoptosis 18: 589-604, 2013

40. Mukherjee S, Mazumdar M, Chakraborty S, Manna A, Saha S, Khan P, Bhattacharjee P, Guha D, Adhikary A, Mukhjerjee S, et al: Curcumin inhibits breast cancer stem cell migration by amplifying the E-cadherin/ $\beta$-catenin negative feedback loop. Stem Cell Res Ther 5: 116, 2014.

41. Saha S, Mukherjee S, Mazumdar M,Manna A,Khan P, Adhikary A, Kajal K, Jana D, Sa G, Mukherjee S, et al: Mithramycin A sensitizes therapy-resistant breast cancer stem cells toward genotoxic drug doxorubicin. Transl Res 165: 558-577, 2015.

42. Hossain DM, Panda AK, Manna A, Mohanty S, Bhattacharjee P, Bhattacharyya S, Saha T, Chakraborty S, Kar RK, Das T, et al: FoxP3 acts as a cotranscription factor with STAT3 in tumorinduced regulatory T cells. Immunity 39: 1057-1069, 2013.

43. Saha S, Adhikary A, Bhattacharyya P, Das T and Sa G: Death by design: Where curcumin sensitizes drug-resistant tumours. Anticancer Res 32: 2567-2584, 2012

44. Hanahan D and Weinberg RA: The hallmarks of cancer. Cell 100: $57-70,2000$

45. Scian MJ, Stagliano KE, Anderson MA, Hassan S, Bowman M, Miles MF, Deb SP and Deb S: Tumor-derived p53 mutants induce NF-kappaB2 gene expression. Mol Cell Biol 25: 10097-10110, 2005.

46. Schumm K, Rocha S, Caamano J and Perkins ND: Regulation of p53 tumour suppressor target gene expression by the p52 NF-kappaB subunit. EMBO J 25: 4820-4832, 2006.

47. Furia B, Deng L, Wu K, Baylor S, Kehn K, Li H, Donnelly R, Coleman $\mathrm{T}$ and Kashanchi F: Enhancement of nuclear factorkappa B acetylation by coactivator p300 and HIV-1 Tat proteins. J Biol Chem 277: 4973-4980, 2002.

48. Webster GA and Perkins ND: Transcriptional cross talk between NF-kappaB and p53. Mol Cell Biol 19: 3485-3495, 1999.

49. Iyer NG, Chin SF, Ozdag H, Daigo Y, Hu DE, Cariati M, Brindle K, Aparicio S and Caldas C: p300 regulates p53-dependent apoptosis after DNA damage in colorectal cancer cells by modulation of PUMA/p21 levels. Proc Natl Acad Sci USA 101: 7386-7391, 2004.

50. Zhong H, Voll RE and Ghosh S: Phosphorylation of NF-kappa B p65 by PKA stimulates transcriptional activity by promoting a novel bivalent interaction with the coactivator $\mathrm{CBP} / \mathrm{p} 300$. Mol Cell 1: 661-671, 1998. 